\begin{tabular}{|l|l|l||}
\hline \multicolumn{2}{|c|}{ PublisherInfo } \\
\hline \hline PublisherName & $:$ & BioMed Central \\
\hline \hline PublisherLocation & $:$ & London \\
\hline \hline PublisherImprintName & $:$ & BioMed Central \\
\hline \hline
\end{tabular}

\title{
Transgene switch
}

\begin{tabular}{|l|l|l||}
\hline \multicolumn{2}{|c|}{ ArticleInfo } \\
\hline \hline ArticleID & $:$ & 4564 \\
\hline \hline ArticleDOI & $:$ & $10.1186 /$ gb-spotlight-20020828-02 \\
\hline \hline ArticleCitationID & $:$ & spotlight-20020828-02 \\
\hline \hline ArticleSequenceNumber & $:$ & 230 \\
\hline \hline ArticleCategory & $:$ & Research news \\
\hline ArticleFirstPage & $:$ & 1 \\
\hline \hline ArticleLastPage & $:$ & 2 \\
\hline \hline & & RegistrationDate : 2002-8-28 \\
\hline ArticleHistory & $:$ & OnlineDate \\
\hline \hline ArticleCopyright & $:$ & BioMed Central Ltd2002-8-28 \\
\hline \hline ArticleGrants & $:$ & \\
\hline \hline ArticleContext & $:$ & 130593311 \\
\hline \hline
\end{tabular}




\section{Jonathan B Weitzman}

Email: jonathanweitzman@hotmail.com

The ability to regulate transgene expression levels is essential for many functional genomic and therapeutic applications. In an Advanced Online Publication in Nature Biotechnology, Weber et al. describe the development of E.REX, a novel gene regulation system that exploits components of the Escherichia coli erythromycin-resistance regulon (Nature Biotechnology, 19 August 2002, DOI:10.1038/nbt731). They designed both EOFF and EON systems that are respectively repressed or induced using macrolide antibiotics (including erythromycin, clarithromycin and roxithromycin). Weber et al. demonstrated that the E.REX systems can function in mammalian cell lines in culture and in microencapsulated cells transplanted into mice. The binary E.REX system is functionally compatible with the tetracyline-responsive systemallowing for the design of simultaneously regulated multigene applications.

\section{References}

1. The impact of mammalian gene regulation concepts on functional genomic research, metabolic engineering, and advanced gene therapies.

2. Nature Biotechnology, [http://biotech.nature.com]

3. Transcriptional activation by tetracyclines in mammalian cells. 